\title{
Physicochemical Characteristics and Antioxidant Capacity of Traditional Yogurt Fortified with Grape (Vitis vinifera L.) Seed Extract at Different Levels
}

\author{
Dilek DEMİRBÜKER KAVAKํ, Bilge AKDENİZ* \\ ${ }^{1}$ Engineering Faculty, Food Engineering Department, Afyon Kocatepe University, Afyonkarahisar 03200, Turkey
}

\begin{abstract}
The aim of this study is to obtain the grape seed extract with high antioxidant activity and to investigate the quality characteristics of traditional yogurts fortified with seed extracts at different concentrations. For this aim, batch hot water extraction was conducted and extraction conditions were optimized to produce Vitis vinifera $L$. grape seed extract using with the highest antioxidant activity. The fortification of yogurts was conducted at 0.10.15 and $0.2 \mathrm{~g} / 100 \mathrm{~g}$ extract level and antioxidant, physicochemical, microbial and sensory characteristics of the yogurt samples were analyzed. Results showed that antioxidant activity of fortified yogurts were higher and up to $14 \%$ more antioxidant activity was detected compared to the control samples. Yogurt samples preserved their physicochemical characteristics. Although sample with $0.1 \mathrm{~g} / 100 \mathrm{~g}$ extract had highest scores in overall acceptance, the sample containing the highest extract concentration of $0.2 \mathrm{~g} / 100 \mathrm{~g}$, exhibited negative perceptions by panelists in sensorial analysis. In conclusion, grape seed may be used in traditional yogurt production by improving the taste and antioxidant potential. The fortification levels of $0.1-0.15 \mathrm{~g} / 100 \mathrm{~g}$ grape seed extract might be more feasible in functional yogurt production and might be more recommended for consumer's appreciation in terms of positive health effects.
\end{abstract}

Keywords: Grape Seed, Extraction, Yogurt, Functional Food, Antioxidant

\section{Üzüm (Vitis vinifera L.) Çekirdeği Ekstraktı ile Zenginleştirilmiş Geleneksel Yoğurdun Fizikokimyasal Özellikleri ve Antioksidan Kapasitesi}

ÖZ

$\mathrm{Bu}$ çalışmanın amacı, antioksidan aktivitesi yüksek üzüm çekirdeği ekstraktı elde etmek ve farklı konsantrasyonlardaki çekirdek ekstraktları ile takviye edilmiş geleneksel yoğurtların kalite özelliklerini araştırılmasıdır. Bu amaçla ilk olarak sıcak su ekstraksiyonu uygulanarak en yüksek antioksidan aktiviteye sahip Vitis vinifera L. üzüm çekirdeği ekstraktı üretmek için ekstraksiyon koşulları optimize edilmiştir. Yoğurtların zenginleştirilmesi 0.1 - 0.15 ve $0.2 \mathrm{~g} / 100 \mathrm{~g}$ ekstrakt düzeyinde yapılmıştır. Yoğurt numunelerinin antioksidan, fizikokimyasal, mikrobiyal ve duyusal özellikleri analiz edilmiştir. Sonuçlara göre, zenginleştirilmiş yoğurt numunelerinin antioksidan aktivitesinin daha yüksek olduğunu ve kontrol numunelerine kiyasla \% 14'e kadar daha fazla antioksidan aktivite gösterdikleri tespit edilmiştir. Yoğurt numunelerinin ise fizikokimyasal özelliklerini korunmuştur. Duyusal analizlerde $0.1 \mathrm{~g} / 100 \mathrm{~g}$ ekstrakt içeren örnekler genel kabul görmede en yüksek puana sahip olmasına rağmen, $0.2 \mathrm{~g} / 100 \mathrm{~g}$ içeren örnekler panelistlerce olumsuz algilanmışır. Sonuç olarak, üzüm çekirdeği ekstraktı geleneksel yoğurt üretiminde tat ve antioksidan özelliğini arttırmak için kullanılabilir. 0.1-0.15 g / 100 g düzeyinde üzüm çekirdeği ekstraktı ile zenginleştirme, fonksiyonel yoğurt üretiminde makul olmakta ve olumlu sağlık etkileri açısından tüketicilerin beğenisine daha fazla hitap etmektedir.

Anahtar Kelimeler: Üzüm Çekirdeği, Ekstraksiyon, Yoğurt, Fonksiyonel Gıda, Antioksidan

To cite this article: Demirbüker Kavak D. Akdeniz. B. Physicochemical Characteristics and Antioxidant Capacity of Traditional Yogurt Fortified with Grape (Vitis vinifera L.) Seed Extract at Different Levels. Kocatepe Vet J. (2019) 12(4):389-395. 


\section{INTRODUCTION}

Grape fruit is a rich source of phytochemicals. 60-70 $\%$ of the extractable polyphenols of grape tissues exist in the grape seed, $28-35 \%$ in the fruit peel and $10 \%$ in the fruit meat (Shi et al. 2003, Akdeniz 2010). Amoung these, the grape seeds with high polyphenol content appear as output material during wine, grape juice and grape molasses production. Grape seed contains polyphenols, vitamins, and minerals, (Ranjitha et al. 2014, So-Young et al. 2006). Due to its high antioxidant properties, it was reported to have protective effects on cells, cardiovascular diseases, also act as antiaging and immune-regulatory agent (Shi et al. 2003, Bagchi et al. 2000, Sato et al. 1999, Saito et al. 1998, Jayaprakash et al. 2001, Mandic et al. 2009). Therefore, grape seed extract is a well-known and popular dietary supplement and especially used in foods to provide functionality. Grape seed extract can be obtained from grape seeds using different extraction techniques. However, the bioactivity of the extracts from plants may vary on the extraction conditions such as temperature, solvent composition and time (Kavak and Akdeniz, 2019, Kavak and Kececi 2019, Kavak 2017). Therefore to obtain a bioactive grape seed extract such as having high antioxidant activity, suitable extraction conditions should be set (So-Young et al. 2006, Jayaprakash et al. 2003).

The word "yogurt" is derived from the Turkish word and it is a traditional food in the Balkans and the Middle East (Tamime and Deeth 1980). Yogurt is a fermented milk product which is formed as a result of the culture activities added to milk. As a nutritional source, it has an important biological value for all age groups (Granato et al. 2010). Fermentation occurs in yogurt with lactic acid bacteria and as a result of fermentation, several metabolites with natural biological activity such as antimicrobials against some pathogenic microorganisms are formed (Con et al. 1996). Due to the competitive activity of microorganisms present in the structure of yogurt and the presence of antimicrobial agents, yogurt has a protective effect against a number of infections causing gastrointestinal and urogenital diseases.

Natural products such as grapes, edible berries were successfully explored in different functional foods due to their considerable bioactivities (Jang et al. 1997, Nile and Park 2014). There are different studies using fruit juices, powders, and extracts to investigate their potential as functional ingredients in the dairy sector (Nguyen and Hwang 2016, Wallaca and Guisti, 2008). Families with children are the core consumers of dairy products such as yogurt and it is essential to explore new potent uses of grape seed dairy sector. Therefore, the aim of this study is to obtain the grape (Vitis vinifera L.) seed extract with high antioxidant activity and to investigate the quality characteristics of traditional yogurts fortified with extracts at different concentrations.

\section{MATERIALS and METHODS}

\section{Materials}

Seeds of grape (Vitis vinifera L.) were obtained from local herbalist (Afyonkarahisar, Turkey). 2,2Diphenyl-1-picryl-hydrazyl (DPPH), $\mathrm{NaOH}$ were purchased from Sigma (Sigma-Aldrich $\mathrm{GmbH}$, Germany). Plate count Agar (PCA) and Violet Red Bile Agar (VRBA) (Merck, Germany) were used for microbiological analysis.

\section{Obtaining Grape Seed Extracts}

To produce grape seed extracts, the seeds were grounded and extracted by hot water extraction process $(1: 10 \mathrm{w} / \mathrm{v} ; \mathrm{mg}$ seed per $\mathrm{mL}$ water). Experimental design for the extraction was shown in Table 1. Aqueous extracts were lyophylized (Lyoquest-Telstar, Japan), sealed in tests tubes and stored under refrigerated conditions $\left(+4 \pm 1{ }^{\circ} \mathrm{C}\right)$ until usage.

\section{Production of Yogurt Using Grape Seed Extract}

Yogurt is produced in traditional method. Cow milk is pasteurized in a household container at $\sim 89 \pm 2^{\circ} \mathrm{C}$ for 5 min. Pasteurized cow milk was cooled to $\sim 44$ ${ }^{\circ} \mathrm{C}$. The plain yogurt was mixed in glass container until it was liquid, and the warm milk was added into the mixture where the weight percentage of plain yogurt in milk was $3 \%(w / w)$. Samples were stirred for $\sim 1$ minute for the yogurt to dissolve well into the milk. Samples were stored at stable temperature of $43 \pm 1^{\circ} \mathrm{C}$ in oven for the incubation of culture for 3.5 hours to a $\mathrm{pH}$ value of 4.4-4.6. After curd formation samples were cooled to $+4 \pm 1{ }^{\circ} \mathrm{C}$ and kept for 1 hour to stabilize the curd structure. Grape seed extracts were added to the samples and completely stirred. Samples were stored at $+4^{\circ} \mathrm{C} \pm 1$ for 5 days before the analysis. The codes of the samples were given in Table 2.

\section{Antioxidant Activity Assays}

Antioxidant activity of extracts and yogurt samples were determined by DPPH free radical scavenging assay. $50 \mu \mathrm{L}$ sample was vortexed with DPPH solution. The mixture was incubated at room temperature for $1 \mathrm{~h}$ at dark. The absorbance of the samples was measured at $517 \mathrm{~nm}$ using UV-Vis Spectrophotometer. The antioxidant activity was expressed in terms of percentage of radical scavenging $\mathrm{AA}(\%)$ :

$$
A A(\%)=\frac{\left(A_{c}-A_{t}\right)}{A_{c}} \times 100
$$

where $A_{c}$ is the absorbance of control (containing all reagents except the test compound ) and $A_{t}$ is the absorbance of test sample, respectively. 


\section{Pysicochemical Analysis of Yogurt Samples}

Samples stored for 5 days at refrigerated conditions were analyzed for their dry matter, by gravimetric method, acidity by titrating with $0.1 \mathrm{M} \mathrm{NaOH}$ (until the faint pink color appeared and stable for 2 minutes) in terms of Soxhelet Henkel: ${ }^{\circ} \mathrm{SH}$, for $\mathrm{pH}$ by diluting sample in a ratio of $1 / 10$ with distilled water using $\mathrm{pH}$ meter (Ohaus 3100, USA) (Tekinşen et al. 2002).

\section{Microbiological Analysis of Yogurt Samples}

Samples were evaluated for their total mesophilic aerobic bacteria (TMAB) and total coliform bacteria using PCA at $37^{\circ} \mathrm{C}$ incubation for 72 hours, and VRBA at $35^{\circ} \mathrm{C}$ for 48 hours incubation under aerobic conditions, respectively (Harrigan and McCance 1976).

\section{Sensorial Analysis of Yogurt Samples}

The sensorial characteristics of samples were measured using hedonic test by a total of 12 pretrained individuals (4 males, 8 females). Yogurt samples of $\sim 40 \mathrm{~mL}$ were put in white plastic cups. They served at room temperature with random 3 digit codes in a random order. Water was provided for panelists to rinse their mouth between samples. The evaluation was based on the appearance, taste and color, mouth feel and overall acceptance criteria by scoring on 9 point hedonic scale (Altuğ 1993).

\section{RESULTS and DISCUSSION}

\section{Antioxidant Activity of Extracts}

To obtain grape seed extract having the highest antioxidant activity, the effect of extraction temperature and time was investigated to optimize the extraction conditions and the results were shown in Figure 1 and 2. Results showed that increase of temperature around from 40 to $55^{\circ} \mathrm{C}$ caused an increase in antioxidant activity $\sim 8 \%$ for 60 minutes hot water extraction (Figure 1).

It was reported that temperature was an important factor in extraction since it is highly effective on diffusion of the molecules (Majd et al. 2014, Kavak and Ülkü 2015, Cacace and Mazza, 2003). But, in extraction processes the temperature should not be so high to avoid degradation of the phenolics compounds thus an upper limit to optimize the bioactivity is critical (Kavak and Akdeniz 2019). The antioxidant activity was nearly same for 45 and $55^{\circ} \mathrm{C}$. Therefore the working temperature for the following extraction process was chosen as $45^{\circ} \mathrm{C}$ to obtain the grape extracts with the highest antioxidant activity ( Figure 2). In the second step, effect of time on $\mathrm{AA} \%$ was the highest for 90 minutes of extraction. Therefore those results revealed that the optimum extraction process was $45^{\circ} \mathrm{C}$ for 90 min within the chosen experimental parameter's range and those extracts with the highest antioxidant activity could be used for further steps to produce functional yogurt.

\section{Antioxidant Activity of Yogurt}

To investigate the effect of extract addition on the antioxidant activity, extracts obtained at optimized conditions (having the highest antioxidant activity as previously mentioned) were added to yogurt samples and antioxidant activities of the samples were investigated. Yogurt contains many bioactive components such as casein where it was reported that casein as a major protein constituent of yogurt and had also antioxidant activity (Kavak and Akdeniz 2016, Silva and Malcata 2005). Therefore results in Table 3 indicated a considerable antioxidant activity (around 54\%) even in YK samples. The fortification of traditional yogurt with seed extracts $(0.2 \mathrm{~g} / 100 \mathrm{~g})$ increased $\mathrm{AA} \%$ to 68.5 where this increase in $\mathrm{AA} \%$ with increase in extract concentration is in good agreement with previous reports (Shyamala et al. 2005). Additionally the antioxidant activity measured at the $5^{\text {th }}$ day of storage revealed that activity was preserved in refrigerated conditions indicating the stability of the functional product over time (Dabija et al. 2018).

\section{Pysicochemical Analysis Results}

The results of physicochemical analysis were shown in Table 4. The total acidity represents the amount of lactic acid produced during fermentation in the yogurt and varied between 36.4 and 38.1 which were in good agreement with the previous reports for the yogurt stored for 5 days at $+4{ }^{\circ} \mathrm{C}$ (Tomovska et al. 2016). Dry matter contents were almost same for the control and extract added samples which was consistent with the previous reports about the traditional yogurts where $13.3 \%$ dry matter was reported. The $\mathrm{pH}$ change for the fortification of yogurt is reported to depend on the nature of the added component as well as it was related to the developmentt of the growth of the bacteria in samples (Pelaes et al. 2015). In literature, the addition of hawthorn extract ( in $0.5 \%$ concentration) affected the $\mathrm{pH}$ and resulted a decrease in yogurt acidity but the addition Pleurotus ostreatus aqueous extract did not affect the $\mathrm{pH}$ where the $\mathrm{pH}$ of the control sample was approximately the same as pH of other samples (Dabija et al. 2018, Pelaes et al. 2015). However, results in Table 3 indicated that the $\mathrm{pH}$ values of samples slightly decreased during storage at $+4{ }^{\circ} \mathrm{C}$ and with the addition of grape seed extracts. The decrease in acidity of yogurt after the production was clear with the extracts added samples compared to the control sample.

\section{Microbiological Analysis Results}

The total coliform bacteria group can be regarded as a large collection of different kinds of bacteria where there is a strong relationship between yogurt safety and quality. Results in Table 5 showed that total 
coliform bacteria were under the detection limit of 1 $\log \mathrm{cfu} / \mathrm{g}$. These results indicated the raw materials quality, adequate heat treatment applications or hygienic production. The total mesophilic aerobic bacteria counts of the samples ranged between 7.29$8.24 \log \mathrm{cfu} / \mathrm{g}$. In literature, it was reported that flavor additives had no effect on the mesophilic aerobic count in yogurt (Con et al. 1996). But this study showed that there was a slight decrease in TMAB with fortification of yogurt with grape seed extract.

\section{Sensorial Analysis Results}

Figure 3 shows the sensory analysis results of the yogurt samples fortified with grape seed extract in different concentrations. Results showed that fortifying yogurt with grape seed affected the sensory scores of quality attributes. The impact of fortification on color was distinct where Y2 had the highest (8.9) and YK took the lowest score of 7.8.
The grape seed extract has orange-light brown color due to its pigments and this might have positively contributed to yogurt color. Similar results were previously reported in literature (Nguyen and Hwang 2016). Overall acceptance scores indicated that Y1 got the highest score (8.1) where it was 7.6 for YK. Although the addition of extract was more acceptable for all characteristic for $\mathrm{Y} 1$ and $\mathrm{Y} 2$ compared to control samples, the values of $\mathrm{Y} 3$ were the lowest except color. Those results revealed that higher amounts of extract addition were not appreciated. Since the grape seed extract itself usually has astringent taste, higher concentrations $(0.2 \mathrm{~g} / 100 \mathrm{~g})$ might possibly showed negative effects on other sensorial attributes. Therefore addition of 0.1-0.15 $\mathrm{g} / 100 \mathrm{~g}$ grape seed extract might be recommended for consumer's appreciation in terms of positive health effects.

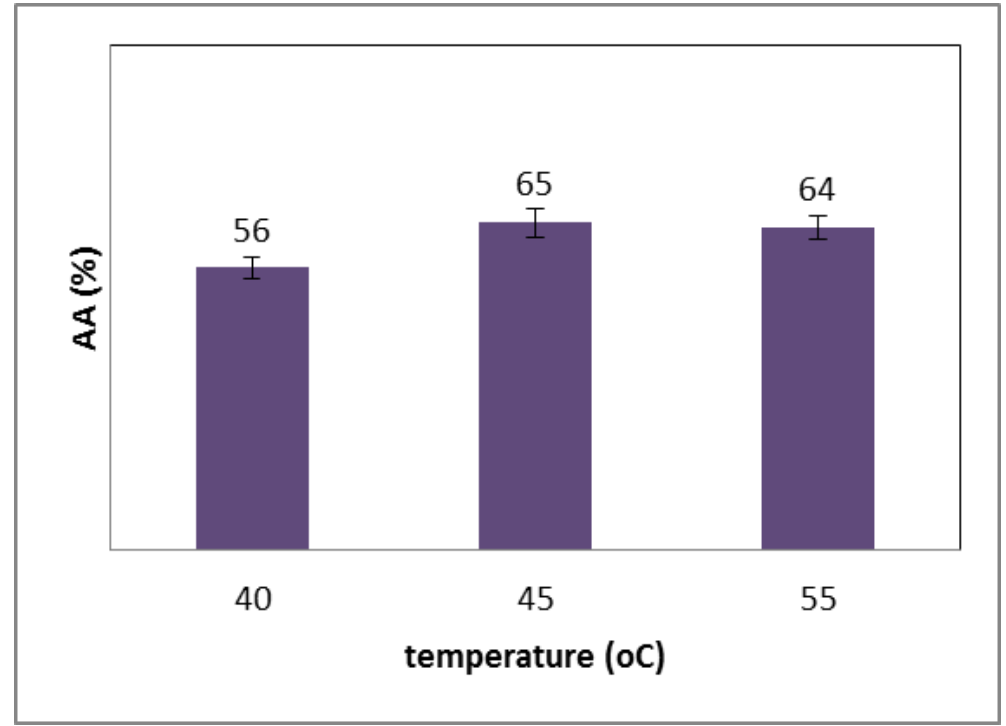

Figure 1. Effect of extraction temperature on antioxidant activity in terms of radical inhibition $(1 \mathrm{~g} / 10 \mathrm{~mL}$ extract; extraction time $60 \mathrm{~min}$.)

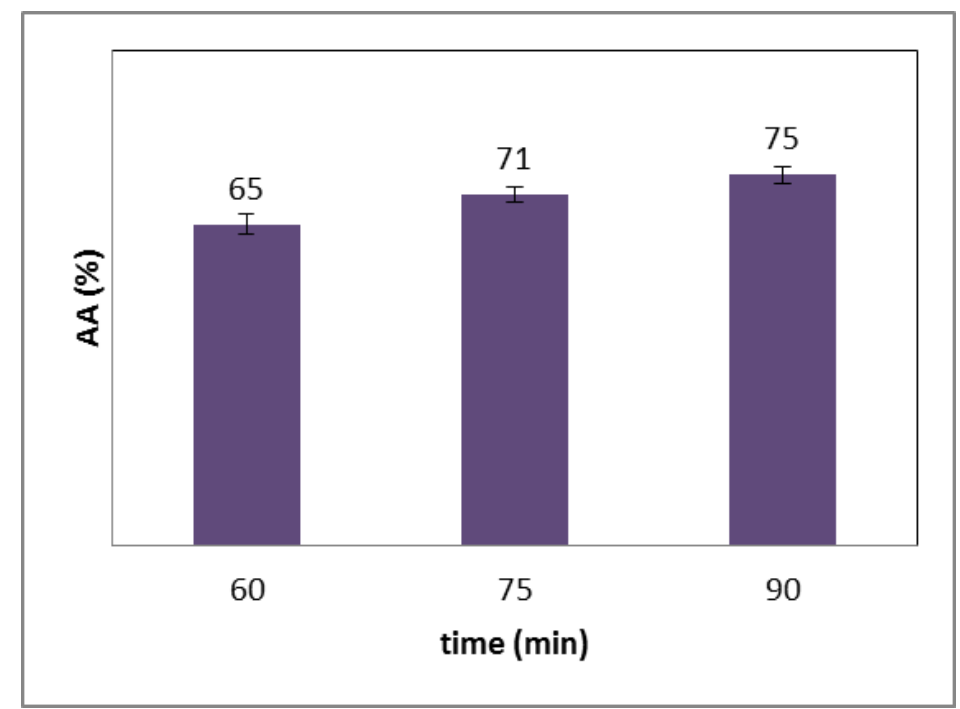

Figure 2. Effect of extraction time on antioxidant activity of extracts $\left(1 \mathrm{~g} / 10 \mathrm{~mL}\right.$ extract; extraction temperature $\left.45^{\circ} \mathrm{C}\right)$ 


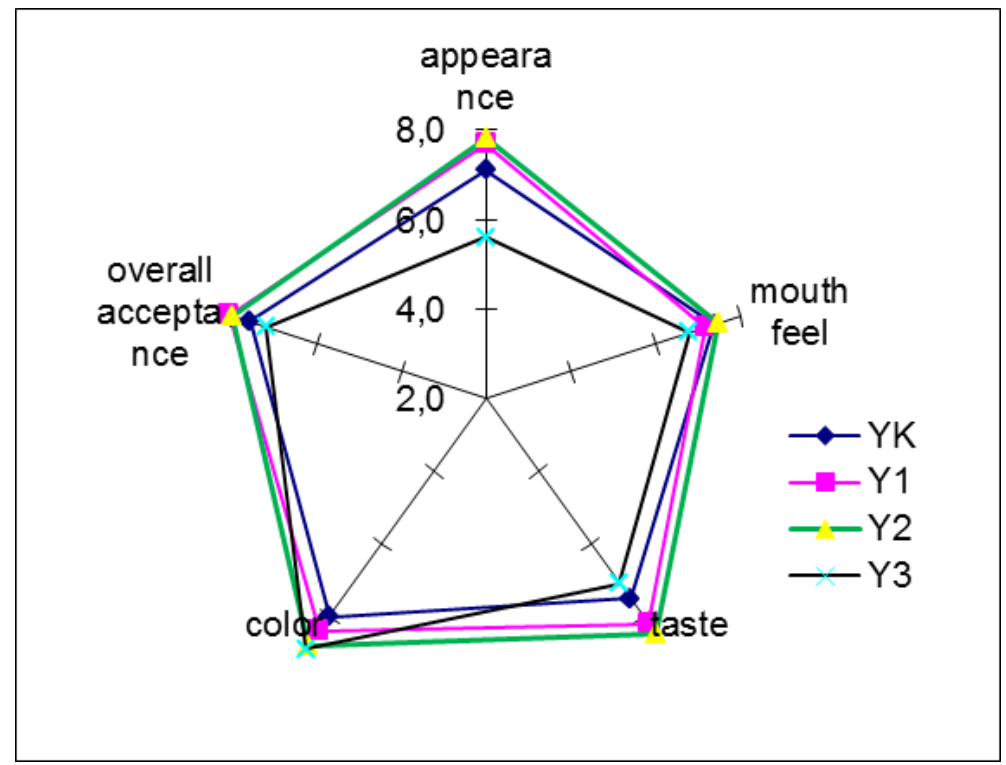

Figure 3. Sensory scores of yogurt samples

Table 1. The parameters of experimental design used for extraction

\begin{tabular}{cc} 
Temperature $\left({ }^{\circ} \mathbf{C}\right)$ & Time (min) \\
\hline 40 & 60 \\
45 & 75 \\
55 & 90 \\
\hline
\end{tabular}

Table 2. Codes and Definitions of the Samples

\begin{tabular}{cc}
\hline Sample Code & Definition \\
\hline YK & Control sample (with no extract) \\
Y1 & Sample with $0.1 \mathrm{~g}$ extract $/ 100 \mathrm{~g}$ yogurt sample \\
Y2 & Sample with $0.15 \mathrm{~g}$ extract $/ 100 \mathrm{~g}$ yogurt sample \\
Y3 & Sample with $0.2 \mathrm{~g}$ extract $/ 100 \mathrm{~g}$ yogurt sample \\
\hline
\end{tabular}

Table 3. Antioxidant activity of yogurt samples

\begin{tabular}{cc} 
Samples & AA (\%) \\
YK & $54.2 \pm 2.3$ \\
Y1 & $58.3 \pm 2.2$ \\
Y2 & $63.6 \pm 1.8$ \\
Y3 & $68.5 \pm 2.1$ \\
\hline
\end{tabular}

Table 4. Pysicochemical analysis results of yogurt samples

\begin{tabular}{cccc}
\hline Samples & Dry Matter (\%) & ${ }^{\circ}$ SH & pH \\
\hline YK & $12.1 \pm 0.3$ & $37.2 \pm 0.4$ & $4.24 \pm 0.04$ \\
Y1 & $12.2 \pm 0.7$ & $36.4 \pm 0.6$ & $4.16 \pm 0.05$ \\
Y2 & $12.1 \pm 0.8$ & $37.2 \pm 0.8$ & $4.11 \pm 0.06$ \\
Y3 & $12.3 \pm 0.2$ & $38.1 \pm 0.5$ & $4.08 \pm 0.03$ \\
\hline
\end{tabular}

Table 5. Microbial analysis results of yogurt samples (log cfu/g)

\begin{tabular}{ccc} 
Samples & Total coliforms & TMAB \\
YK & $<1.0$ & 8.24 \\
Y1 & $<1.0$ & 7.61 \\
Y2 & $<1.0$ & 7.33 \\
Y3 & $<1.0$ & 7.29 \\
\hline
\end{tabular}




\section{CONCLUSION}

In this research, it was demonstrated that grape seed extract can be successfully used for the fortification of traditional yogurt. The addition of grape seed extract did not change the physicochemical quality characteristics of yogurt samples. There was an increase in antioxidant activities of traditional yogurt samples and sensory analyzes showed that the addition moderate (0.1-0.15 g/ $100 \mathrm{~g})$ concentrations of extract had a desirable effect on sensorial characteristics. Therefore, the fortification of traditional yogurt with of low concentrations of grape seed extract may result favorable product in terms of sensorial characteristics and the yogurt gains functionality which makes this healthier dairy product more desirable in terms of consumer perception.

\section{REFERENCES}

Akdeniz DB. Researches about amphelograpy and quality characteristics of some native grape varieties (Vitis vinifera $s p$.) and investigation of chemical and organoleptic quality properties, colour index and total phenolic compound contents of wines made from these varieties in Afyonkarahisar region. $\mathrm{PhD}$ thesis, Ege Üniversity Graduate School of Natural and Applied Sciences, İzmir, 2010.

Altug, T. Sensory Test Techniques, Ege University Publication No. 28 Izmir, Turkey, 1993 (in Turkish)

Bagchi D, Bagchi M, Stohs SJ, Das DK, Ray SD, Kuszynski CA, Joshi SS, Pruess HG. Free radicals and grape seed proanthocyanidin extract: importance in human health and disease prevention. Toxicology. 2000; 148:187-197.

Cacace JE, Mazza G. Mass transfer process during extraction of phenolic compounds from milled berries. Journal of Food Engineering. 2003; 59(4):379-389.

Con AH, Cakmakci S, Caglar A, Gokalp HY. Effects of different fruits and storage periods on microbiological qualities of fruit-flavored yogurt produced in Turkey. Journal of Food Protection. 1996; 59:402-406.

Dabija A, Codina GG, Ropciuc S, Gatlan A, Rusu L. Assessment of the antioxidant activity and quality attributes of yogurt enhanced with wild herbs extracts. Hindawi Journal of Food Quality. 2018; 2018:1-12., Doi: https://doi.org/10.1155/2018/5329386

Granato D, Branco GF, Cruz AG, Faria JAF, Shah NP. Probiotic dairy products as functional foods. Comprehensive Reviews in Food Science and Food Safety. 2010; 9: 455-470.

Harrigan WF, McCance ME. Laboratory Methods in Food and Dairy Microbiology. Academic Press Inc. London, UK. 1976; 452p.

Jang, MS, Cai EN, Udeani GO, Slowing KV, Thomas CF, Beecher CW, Fong $\mathrm{HH}$, Farnsworth NR, Kinghorn AD, Mehta RG, Moon RC, Pezzuto JM. Cancer chemopreventive activity of resveratrol, a natural product derived from grapes. Science. 1997; 275(5297): 218-220.

Jayaprakash GK, Selvi T, Sakariah KK. Antibacterial and antioxidant activities of grape (Vitis vinifera) seed extracts. Food Research International. 2003; 36:117-122.

Jayaprakash GK, Singh RP, Sakariah KK. Antioxidant activity of grape seed (Vitis vinifera) extracts on peroxidation models in vitro. Journal of Food Science. 2001; 73:285290.

Kavak DD, Akdeniz B. Potential Application of Casein for the Inhibition of $\beta$-Glucuronidase Activity. Afyon Kocatepe University Journal of Science and Engineering. 2016; 16(special issue 1):74-78

Kavak DD, Akdeniz B. Sorbus umbellata (Desf.) Fritsch var. umbellata Leaves: Optimization of extraction conditions and investigation antimicrobial, cytotoxic, and $\beta$ Glucuronidase inhibitory potential. Plant Foods for Human Nutrition. (2019). Doi: https://doi.org/10.1007/s11130-019-00743-9

Kavak DD, Kececi S. Extraction of phenolic antioxidants from Pyrus elaeagrifolia Pallas: process optimization, investigation of the bioactivity and $\beta$-glucuronidase inhibitory potential. Food Measurement and Characterization (2019). Doi: https://doi.org/10.1007/s11694-019-002108

Kavak DD, Ülkü S. Kinetic and equilibrium studies of adsorption of $\beta$-glucuronidase by clinoptilolite-rich minerals. Process Biochemistry. 2015; 50:221-229.

Kavak DD. Optimization of extraction time, temperature and solvent concentration for the antioxidant activity and total phenolic content of the Cydonia oblonga mill. Leaves. American-Eurasian Journal of Sustainable Agriculture 2017; 11(6): 1-6.

Kim SY, Jeong SM, Park WP, Nam K.C, Ahn DU, Lee SC. Effect of heating conditions of grape seeds on the antioxidant activity of grape seed extracts. Food Chemistry. 2006; 97:472-479.

Majd MH, Rajaei A, Bashi DS, Mortazavi SA, Bolourian S. Optimization of ultrasonic-assisted extraction of phenolic compounds from bovine pennyroyal (Phlomidoschema parviflorum) leaves using response surface methodology. Industrial Crops and Products. 2014; 57:195-202.

Mandić AI, Djilas SM, Čanadanović-Brunet JM, Ćetković GS, Vulić JJ. Antioxidant activity of white grape seed extracts on DPPH radicals. Acta Periodica Technologica. 2009; 40:53-61

Nguyen L, Hwang ES. Quality characteristics and antioxidant activity of yogurt supplemented with aronia (Aronia melanocarpa) juice. Preventive Nutrition and Food Science. 2016; 21(4):330-337.

Nile SH, Park SW. Edible berries: bioactive components and their effect on human health. Nutrition. 2014; 30(2):134 144.

Pelaes Vital AC, Goto PS, Hanai LN, Gomes-da-Costa SM, Filho BA, Nakamura CV, Matumoto-Pintro PT. Microbiological, functional and rheological properties of low fat yogurt supplemented with Pleurotus ostreatus aqueous extract. LWT-Food Science and Technology. 2015; 64(2):10281035.

Ranjitha CY, Priyanka S, Deepika R, Smitha Rani GP, Sahana J, Prashith Kekuda TR. Antimicrobial activity of grape seed extract. World Journal of Pharmacy and Pharmaceutical Sciences. 2014; 3(8):1483-1488.

Saito M, Hosoyama H, Ariga T, Kataoka S, Yamaji N. Antiulcer activity of grape seed extract and procyanidins. Journal of Agricultural and Food Chemistry. 1998; 46:1460-1464.

Sato M, Maulik G, Ray PS, Bagchi D, Das DK Cardioprotective effects of grape seed proanthocyanidin against ischemic reperfusion injury. Journal of Molecular and Cellular Cardiology. 1999; 31:1289-1297. 
Shi J, Yu J, Pohorly JE, Kakuda YJ. Polyphenolics in grape seeds-biochemistry and functionality. Journal of Medicinal Food. 2003; 6(4):291-299.

Shyamala BN, Gupta S, Jyothi A, Prakas LJ. Leafy vegetable extracts-antioxidant activity and effect on storage stability of heated oils. Innovative Food Science and Emerging Technologies. 2005; 6(2): 239-245.

Silva SV, Malcata FX. Caseins as source of bioactive peptides. International Dairy Journal. 2005; 15(1):1-15.

Tamime AY, Deeth HC. Yogurt: technology and biochemistry. Journal of Food Protection. 1980; 43(12):939-977.

Tekinşen C, Atasever M, Keleş A., Tekinşen KK. Süt, yoğurt, tereyağ1, peynir: üretim ve kontrol. Selçuk Üniversitesi Basımevi, Konya, 2002.

Tomovska J, Gjorgievski N, Makarijoski B. Examination of $\mathrm{pH}$, titratable acidity and antioxidant activity in fermented milk. Journal of Materials Science and Engineering A. 2016; 6(11-12):326-333. doi: https://doi.org/10.17265/2161-6213/2016.11-12.006

Wallace TC, Giusti MM. Determination of color, pigment, and phenolic stability in yogurt systems colored with nonacylated anthocyanins from Berberis boliviana $L$. as compared to other natural/synthetic colorants. Journal of Food Science. 2008; 73(4): 241-248. 